\title{
ECONOMICAL EVALUATION OF NILE TILAPIA (OREOCHROMIS NILOTICUS) CULTURE IN RICE FILEDS RECEIVING VARYING FEEDING INPUTS
}

\author{
Abdel- Rahman A. Salama \\ Department of fish Economic, Central Laboratory for Aquaculture \\ Research at Abbassa, Sharkia Governorate, Egypt.
}

Key words: Nile tilapia, productivity, rice fish culture ,blue green algae, economical efficiency.

\section{ABSTRACT}

$\Gamma^{1}$ his study aimed to evaluate the nutritive value, growth parameters, productivity and economical efficiency of dried blue green algae for feeding Nile tilapia (Oreochromis niloticus) cultured in rice fields. Eight rice fields (one fed. each) were cultivated by rice and divided into four groups, the first group $\left(T_{1}\right)$ of two fields with dried blue green algae at a rate of $5 \%$ of body weight per week, and the second $\left(\mathrm{T}_{2}\right)$ one was fed on artificial diet containing $20 \%$ crud protein. The third group $\left(\mathrm{T}_{3}\right)$ was fed on natural food resulting from fertilization only ( $30 \mathrm{Kg}$. chicken manure/week) and the fourth group $\left(\mathrm{T}_{4}\right)$ has served as a control (without any treatment).All fields were stocked with Nile tilapia (1000 fingerlings/fed.) with an average weight of $30 \mathrm{~g}$. The growing season for tilapia fish was 90 days. Results obtained can be summarized in the following:

- Treatments applied had significant effect on final body weight, specific growth rate, body length and condition factor of Nile tilapia.

- The highest survival rate was obtained with group of fish on $T_{2}$ followed by $T_{1}, T_{3}, T_{4}$ treatments respectively

- The highest net production was recorded with group of fish on $T_{2}$ followed by $T_{1}, T_{3}$ and $T_{4}$ treatments respectively.

- The highest net return was recorded with group of fish on $T_{1}$ followed by $T_{3}, T_{2}$ and $T_{4}$ treatments respectively.

\section{INTRODUCTION}

In 1998, only 12440 tons of fish were produced from 23360 feddan (rice fish integrated system) and this contributed only $2.28 \%$ of the total Egyptian fish production (Abdel-Hakim et al.2000a). 
In aquaculture, feed is the most expensive cost item, commonly contributing between $40-70 \%$ of total variable expenses. Protein is the principal and most expensive component of the diet, where the protein sources in tilapia feeds comprising $55-75 \%$ of the dietary material cost. Consequently protein cost is usually given the first priority in formulating fish feeds (Hanley, 2000).

Average body weight of Nile tilapia (Oreochromis niloticus) culture in rice fields has been increased from 4.08 to $81.97 \mathrm{~g}$. and the rice yield increased by $148 \mathrm{Kg} /$ feddan, beside $77.9 \mathrm{Kg}$. fish/feddan (Abdel-Hakim et al. 2000). Mohamed Bakeer et al. (2003) reported that the grass carp( 25 g.) which fed on blue - green algae plus Lucerne ( $5 \%$ of body weight/5days a week for 150 days) cultured in earthen pond recorded the highest final body weight and specific growth rate (SGR). The total fish production in rice fields is about 20,000 tons as reported by GAFRD(2001).

The objective of the present study is to evaluate the technical and economic feasibility of cultivating Nile tilapia in rice fields under varying feeding systems.

\section{Location}

\section{MATERIALS AND METHODS}

The present study was carried out in a private rice farm, at Abbassa village, Abu-Hammad, Sharkyia Governorate, Egypt.

\section{Facilities and fish}

Eight rice fields (one fed. each) were cultivated by rice and divided into four groups, the first group of two fields was fed with dried blue - green algae at a rate of $5 \%$ of body weight per week, and the second one was fed on artificial diet ( $20 \%$ crud protein). The third group was fertilized on only with $30 \mathrm{Kg}$. chicken manure/weekly and the fourth group served as control (without any treatment). Rice fields were prepared with ditches in the middle of the pond with a depth and width of $0.75 \times 0.50 \mathrm{~m}$, respectively. Screens were fixed at the end of the canals to prevent fish from escaping or the entrance of foreign fishes into rice fields. Rice was cultivated in the field at first 30 days, and then transplanted in the permanent rice fields. After 7 days of rice transplantation all ponds were stocked with Nile tilapia fingerlings at a density of 1000 fingerlings/feddan with an average initial weight of $30 \mathrm{~g}$. The growing period for tilapia fish was 90 days.

\section{Experimental diet}

Application of chicken manure at a rate of $300 \mathrm{~kg} /$ feddan was carried out before rice transplantation. During the growing period, the 
third group received $30 \mathrm{Kg}$. chicken manure/week. The second group was fed on pellets containing $20 \%$ crude protein at a rate of $2 \%$ daily of fish biomass. Feeding rate of artificial diet was recalculated and adjusted biweekly according to the change in fish biomass as assessed by fish sample. The food pellets were applied once a day for 5 days a week by broadcasting the pond surface near the supply gate. No pesticides were used during the entire experiment. The experimental diet was chemically analyzed according to the methods of AOAC (1990). The chemical compositions of experimental diets are shown in (Table 1 a, b, c.)

\section{Growth performance parameters}

Live body weight and length of a random sample of 150 fish from each pond were taken at start and every 15 days and were recorded till the termination of the experiment. The fish were netted from the water and weighed to the nearest gram. Standard length of fish was measured at the beginning and at the end of the experimental period to the nearest $\mathrm{mm}$. Then the fish were returned immediately to their ponds.

\section{Samples and measurements}

Water temperature, dissolved oxygen and $\mathrm{pH}$ were measured daily at $6^{\circ \circ}$ a.m. and $12^{\circ \circ}$ p.m. using temperature and dissolved oxygen meter (YSI model 57) and pH meter (model Corning 345). Determinations of water quality parameters (alkalinity, phosphorus and ammonia were carried out every two weeks according to the methods of Boyd (1979). Phytoplankton and zooplankton communities in pond water were determined every two weeks according to the methods described by Boyd (1990) and A.P.H.A (1985). Samples were collected from different sites of the trench center randomly to represent the water of the whole rice fields. Parameters of specific growth rate (SGR) and condition factor (K) were calculated according to the following equations: Specific growth rate (SGR) $\mathrm{SGR} \%=100\left(\mathrm{LnW}_{2}-\mathrm{LnW}_{1}\right) / \mathrm{T}_{2}-\mathrm{T}_{1} \quad$ (Bagenal and Tesch, 1978) where $W_{1}$ and $W_{2}$ are the first and following fish weight in grams, $\mathrm{Ln}$ is the natural logarithm and $T$ is the growing period in days.

Condition factor $(\mathrm{K}): \mathrm{K}=$ weight $\mathrm{g} \times 100 /$ length $\mathrm{cm}^{3}$ (Hopkins, 1992)

Where $W$ and $L$ are the individual weight and length of the fish.

After 90 days of fish culture, tilapia was harvested from each field and a sample of 30 fish was randomly taken for body weight and 
body length measures. The rice was harvested after 120 days of sowing.

Statistical analysis:

The statistical analysis of data was carried out by applying the computer program of Harvey (1990).

\section{RESULTS AND DISCUSSION}

\section{Water quality parameters:}

Results of water quality parameters of paddies as affected by receiving varying feeding inputs during the experimental period ( 90 days) as averages of the monthly samples are summarized in table (2) In general, water temperature of the different treatments were 26.55; $26.16 ; 28.00$ and $25.00^{\circ} \mathrm{C}$. for $T_{1} ; T_{2} ; T_{3}$ and $T_{4}$, respectively The least value $25.00^{\circ} \mathrm{C}$ was for $T_{4}$ (control) and the highest $\left(28.00^{\circ} \mathrm{C}\right.$ ) was for $\mathrm{T}_{3}$ (fertilization). The higher difference in water temperatures in fertilized fields may be attributed to the increased organic matter contents of these fields that may lead to temperature increases. These results are in agreement with those of Boyd, (1983); Jobling, (1983) and Abdel -HaKim et al. (2000), who found a slight increase in water temperature with increasing manure and the optimum temperature ranged between 15 and $30^{\circ} \mathrm{C}$ for Nile tilapia (Oreochromis niloticus).

The concentration of dissolved oxygen $(\mathrm{mg} / \mathrm{L})$ for $\mathrm{T}_{3}$ and $\mathrm{T}_{4}$ ranges between 6.12 and $7.00 \mathrm{mg} / \mathrm{L}$. These values are beneficial to fish culture and indicate that water dissolved oxygen was slightly lower in fertilized fields compared to the other fields. These results are in agreement with Boyd (1992), who reported that levels of dissolved oxygen above $4 \mathrm{ppm}$ is considered a limiting factor, below which, fish may live but can not feed or grow well. Averages of available phosphorus ranged between 0.10 and $0.13 \mathrm{mg} / \mathrm{L}$, which represent the normal range of phosphorus in rice fish fields. This range was found to be suitable for growth of fish as reported by Fortes et al. (1986) and Boyd et al. (1981). Nitrite $\left(\mathrm{No}_{2}\right)$ concentrations were higher in $\mathrm{T}_{3}$ (fertilizer) than the other treatments, which may be due to the accumulation of nitrogen from the fertilizer in the ditch (Boyd, 1990).

The average concentration of unionized ammonia $\left(\mathrm{NH}_{3}\right)$ (Table 2) ranged between 0.53 and $0.68 \mathrm{ppm}$ for $T_{4}$ and $T_{3}$. The increase in the total ammonia observed in fertilized treatment may be due to decomposition of the heavy organic load of the unexploited blue green algae which fall to the bottom of the ditches after death. 
The European Inland Fisheries Advisory Commission (1993) reported that the toxic level of $\mathrm{NH}_{4}$ to fish is $2 \mathrm{mg} / \mathrm{L}$.

Averages of $\mathrm{pH}$ values for the treatments $\mathrm{T}_{1 ;} \mathrm{T}_{2} ; \mathrm{T}_{3}$ and $\mathrm{T}_{4}$ were 9.2, 9.0,8.1 and 9.41 , respectively. The lower values of $\mathrm{pH}$ in fertilized paddies may be attributed to the increase in organic matter contents of these paddies, which may lead to lower $\mathrm{pH}$ levels. The acid and alkaline points were found between $\mathrm{pH} 4$ and 14 (Swingle 1961 and Calabrese, 1969).

The values of the total alkalinity, were ranged between 301 and $335 \mathrm{ppm}$ for $T_{4}$ and $T_{3}$. The above results showed that all parameters of water quality were in the suitable range, however fish with $\mathrm{T}_{4}$ (control) recorded minimum levels of $\mathrm{NO}_{2} ; \mathrm{NH}_{3}$ and alkalinity and the highest levels of $\mathrm{DO}$ and $\mathrm{pH}$.

The average values of most water quality parameters were very close for $T_{1} ; T_{2}$ and $T_{3}$.

\section{Phytoplankton}

As shown in Table (3) the total phytoplankton counts for treatments T1; T2; T3 and T4 were 5094, 3673, 4926 and 4532 organisms ML., respectively on the average. The phytoplankton total counts increased in water samples collected from $\mathrm{T} 1, \mathrm{~T} 3$ and the differences were highly significant $(P<0.01)$ and $(p<0.001)$ for the abundance of phytoplankton groups (Chlorophyta, Cyanophyta and the total phytoplankton organisms). These results could be explained by the fact that chicken manure and decomposed blue - green algae have more fertilization potential compared with other treatments. Table (1) revealed that chicken manure contains $1.64 \%$ nitrogen and $0.29 \%$ phosphorus and also the decomposed blue - green algae contain $0.27 \%(\mathrm{~K})$ and $0.89 \%$ phosphorus which may reflect the better fertilization potential of blue - green algae and chicken manure, respectively.

The present study indicates that Chlorophyta was the dominant group followed by Cyanophyta and Bacillarophyta in the all treatment paddies. The community composition of phytoplankton reported in this study is in accordance with the findings of EL-Serafy and EL-Zahaby (1991) and Abdel-Hakime et al (2000) a and b, who pointed out that Chlorophyta predominated all the other groups followed by Cyanophyta and Bacillariophyta.

Table (3) also shows that the average number of zooplankton organisms per liter were higher in water samples of $\mathrm{T} 1$ and $\mathrm{T} 3$ and the differences were significant for Copepoda, Cladocera and total 
zooplankton organisms per liter. The present study indicates that Rotifera is the dominate group followed by Copepoda and Cladocera in all fields. This community composition of zooplankton is in conformity with observations of Abdel-Hakim et al. (2000 a and b).

The present study also indicates that the community composition of phytoplankton and zooplankton in all treatment ponds fluctuated greatly with temperature, fertilization and feeding habits of fish. In this concern, Riely (1947), reported statistically that no strict relationship between the total zooplankton and the total phytoplankton numbers.

\section{Growth performance}

As described in Table (4), the average body weight of Nile tilapia increased from 30.12 to $108.10 ; 120.70 ; 91.71$ and $78.13 \mathrm{~g}$. for $T_{1} ; T_{2} T_{3}$ and $T_{4}$, respectively. Daily gain $(g)$ was between 6.53 and $1.00 \mathrm{~g}$. These values were higher than obtained by Mang-Umphan and Arce (1988); who found that, under the integrated rice fish system, the body weight of Nile tilapia increased from 8.3-8.59 to 33.78$36.69 \mathrm{~g}$. during 75 days rice fish culture period, where fields were supplied with inorganic fertilizers. Table (4) also shows that the body length of Nile tilapia increased from 6.24 to $13.70 ; 14.95 ; 12.96$ and $10.96 \mathrm{~cm}$. for $T_{1}, T_{2}, T_{3}$ and $T_{4}$. After 90 days of culture in rice fields and the values of fish condition factor recorded $4.20 ; 3.61 ; 4.2$ and 5.91 for $T_{1}, T 2$, and $T_{3}$ and $T_{4}$ respectively.

Specific growth rate (SGR) recorded were $1.4 ; 1.5 ; 1.2$ and 1.05 for $T_{1} ; T_{2} ; T_{3}$ and $T_{4}$ respectively. These values are in agreement with that reported by Sadek (1986), Haroon \& Pittman (1997) and Sadek, (1998), who found that SGR of Nile tilapia was 1.8 when cultured in paddies. The high value of daily gain and the other growth traits found in this study may be attributed to the presence of the natural food organisms enhanced by the fertilization of the paddy environment which served as a direct source of food for Nile tilapia (Chapman \& Fernando, 1994).

Table (5) shows that rice yields in the present study were $2640 ; 2560 ; 2544$ and $2440 \mathrm{Kg}$./feddan for $\mathrm{T}_{1} ; \mathrm{T}_{2} ; \mathrm{T}_{3}$ and $\mathrm{T}_{4}$, respectively. So approximately about $5-10 \%$ increase in rice yield was achieved as a result of the integration of fish in rice paddies. The increase in rice yield is in agreement with that obtained by EL-Bolok and Labib (1967), who found that the rice yield increased, by $5-7 \%$ in rice fields. As illustrated in Table (5)the fish yields were 102.69; $115.87 ; 85.29$ and $75.66 \mathrm{Kg}$. for $T_{1} ; T_{2} ; T_{3}$ and $T_{4}$, respectively. The fish yield in the present study was higher than that obtained by 


\section{ECONOMICAL EVALUATION OF NILE TILAPIA CULTURE IN RICE FILEDS}

Haroon \& Pittman (1997) and Abdel-Hakim et al. (2000)b who found that the total fish yields of Nile tilapia were 59.4 and $158.2 \mathrm{~kg} / \mathrm{ha}$ when their initial weights were 3.1 and 30.7 , respectively (Li, 1992), they reported that fish yields vary from $50 \mathrm{~kg} / \mathrm{ha}$ to 2.25 tons/ha, depending unsystematically on country, fish species, density, fish diets and other factors.

\section{Survival Rate}

As shown in Table (5) survival rate were $95 ; 96 ; 93$ and $92 \%$, for $T_{1} ; T_{2} ; T_{3}$ and $T_{4}$, respectively. These results are in agreement with Perez- Athanasiadis and Bellido- de Cedeno (1989), who obtained $90 \%$ survival rate for Nile tilapia in rice culture fields, while Haroon \& Pittman (1997) found a survival rate from 66.4 to $65.6 \%$ for Nile tilapia in paddies for 78 days.

Economic Efficiency.

Table (5) shows the results of economical evaluation including the costs and returns for treatments applied in $\mathrm{kg} . /$ feddan and income in (L.E) for 90 days. Total costs were $1293 ; 1675 ; 1350$ and $1275 \mathrm{~L} . \mathrm{E} /$ feddan for the $\mathrm{T}_{1} ; \mathrm{T} 2 ; \mathrm{T}_{3}$ and $\mathrm{T}_{4}$, respectively. These results revealed that the total cost of T2 (diet with $20 \%$ protein) was the highest than other groups. On the other hand, the total cost of T4 (without treatment) was the lowest due to the absence of input costs. Net returns in L.E per feddan were $1860.45 ; 1463.35 ; 1620.45$ and 1524.3 for $T_{1}, T_{2}, T_{3}$ and $T_{4}$, respectively.

Percentages of net return to total cost ior treatments cited above were $143.8 ; 87.36 ; 120.03$ and $119.55 \%$ for $T_{1}, T_{2}, T_{3}$, and $T_{4}$ respectively, indicating that the highest returns were obtained with the group $\mathrm{T} 1$ (blue green algae at a rate of $5 \%$ of body weight per week) and $\mathrm{T} 3$ (fertilized with $30 \mathrm{~kg}$. chicken manure/weekly).

\section{RECOMMENDATION}

Based on the obtained results, the use of dried blue green algae in rice fish culture could be recommended for Nile tilapia (weighing $30 \mathrm{~g}$ ) and the feeding rate was $5 \%$ of fish body weight every week. 


\section{REFERENCES}

Abdel- Hakim, N. F. ; Soltan, M. A. and Bakeer, M. N. (2000a). Culture of Nile tilapia (Oreochromis niloticus) in rice fish culture system. Conference of Social and Agriculture Development of Sinai (D70-81):171-181

Abdel- Hakim, N. F. ; Bakeer, M. N.and Soltan, M. A. (2000b). Effect of two manuring systems on water quality and plankton communities in fishponds. Conference of Social and Agriculture Development of Sinai (D43-59):47-158

Association of Official Analysis Chemists (AOAC). (1990). Official Methods of Analysis, $15^{\text {th }}$ edo, pp 1298, Virginia. American Public Health Association A.P.H.A. (1985): Standard method for the examination of water and waste water. Ed. American Public Health Association. Washington. 1268pp.

Boyd, C. E. (1979): Water quality in warm water fish ponds. Ed. Claude E. Boyd. Third printing, 1984. Pub. Auburn Univ., Agri.Exp. Station, AID/Dsan- G.G.0039. 359pp.

Bagenal, T. B and tesch, F.W. (1978). Age and growth In Bagenal, T. (Ed.) Methods for Assessment of fish production in Fresh Waters. IBP Handbook 3. Blackwell, Oxford, U.K., $10 !-136$.

Boyd, C. E. and Musing, Y. (1981). Orthophosphate uptake by phytoplankton and sediment. Aquacult., 22:165-173.

Boyd, C. E. (1983). Water quality management for pond fish culture. Elsevier scientific publishing company, New York, 318pp.

Boyd, C. E., (1990). Water quality in ponds for aquaculture. Alabama agric. Experiment station, Auburn univ., Alabama.

Boyd, E. C. (1992). Water quality in warm water fish. Alabama Agric. Experiment station, Auburn Univ., Alabama. 
Calabrese, A. (1969). Effects of acids and alkalies on survival of bluegills and largemouth bass. U.S. fish wild Ser. Tech. Paper 42, 10.

Chapman, G and Fernando, C. H. (1994). the diets and related of feeding of Nile tilapia ( $O$. niloticus $\mathrm{L}$.) and common (Cyprinus carpio L) in Lowland rice fields in northeast Thailand. Aquacult., $123(3-4): 281-307$.

El- Bolock and Labib (1967). Carp culture in the U.A.R FAO fish Rep., 44(2): 164.

El- Serafy, S. S. and AL-Zahaby, S. A. (1991). Plankton in the tradition and improved technique of fish culture, Egypt. J. Appl. Sci. 6(10)991 : 429-440.

European Inland Fisheries Advisory Commission (1993). Water quality criteria for European fresh water fish. Report on Ammonia and Inland Fisheries. Water Res., 7: 1011-1011.

Fortes, R. D. ; Corre, V. L. and Pudadera, E. (1986). Effect of fertilizers and feeds as Nutrient sources on Oreochromis niloticus production in Philippine brackish water ponds. In J. L. MacLean, L. B. Dizon and J. V. Hosilles. The first Asian fisheries forum. Asian fisheries society, Manila, Philippine, pp.121-124.

G.A.F.R.D. General Authority for Fish Resources Development (2001): Cairo, Egypt. Annual report

Haroon, A. K. Y. and Pitmen, K. A. (1997). Rice- fish culture: feeding, growth and yield of two size classes of Puntius goninotus Bleeker and Oreochromis spp. In Bangladesh. Aquacult., 154: 261-281.

Hanley, F. (2000). Digestibility coefficient of feed ingredients for Tilapia. Tilapia aquaculture in the century proceeding from the fifth International symposium on Tilapia aquaculture. September (1) 3-7, 2000, 163-172. Edited by F.Kevin and Jomar. C, Riodejaneiro- Brasil. 
Harvey, W. R. (1990). User's guide for LSMLMW. Mixed model least - squares and maximum likelihood computer program Ohio state University, Columbus, USA.

Hopkins, K. D. (1992). Reporting fish growth: review of the basic. Jour world Aquacult. Soc., 23(3): 179.

Jobling, M. (1983). A short review and critique of methodology used in fish growth and nutrition studies.J. Fish. Biol, 23: 685703.

Li, K. (1992). rice- fish farming system in China: past, present and future. In dela Cruz, C. R., Lightfoot, C., costa-pierce, B.A., Carangal, V. R., Bimbao, M. P. (Eds.). Rice-fish Research and Development in Asia. ICLARM Conf. Proc., 24:17-26.

Mang - Umphan, K. and Arce, R. G. ( 1988 ): Culture of Nile tilapia (Oreochromis nlioticus) in a rice fish culture system using chemical and commercial organic fertilizers, p. 59-62 in Pullin, T. Bhuknswan, $\mathrm{K}$. Tonguthai and L. MacLean (des). The Second International Symposium on Tilapia in Aquaculture ICLARM conference proceeding $15,632 \mathrm{pp}$.

Mohamed N. Bakeer ; Abdel- Rahman A. Salama ; Fayza S. Abbas and Mostafa M. Saiid (2003). Technical and economical evaluation on food type of grass carp (C. idella) reared in earthen ponds. J. Egypt. Acad. Soc. Environ. Develop., (BAquaculture) 4(1): 97-110 (2003).

Perez- Athanasiadis, H. A. and Bellido- de Cedeno, R. (1989). First experince of fish culture in rice fields in Panama. Latinoam Acuicult., 40:58-63

Riely, G. A. (1947). Seasonal fluctuations of the phytoplankton production in New England Coastal Waters. J. Mar. Res., $6(2): 114-125$.

Sadek, S. M. and Abdel- Hakim, N. F (1986). Effect of rice fish culture on rice and fish yields in Egypt. Al- Azhar j. Agric. Res, 157-162. 
Sadek, S. and Moreau, J. (1998). Culture of Macrobrachium Rosenberger in monoculture and polyculture with Oreochromis in paddies in Egypt. Bamidgeh, 50:33-42.

Swingle. H. S. (1961). Relationships of $\mathrm{pH}$ pond water to their suitability for fish culture Proc. Pacific Sci. Congress (1957) vol. 10, fisheries, pp72-75. 
Table (1): The chemical analyses of experimental diets for Nile tilapia in rice fish culture.

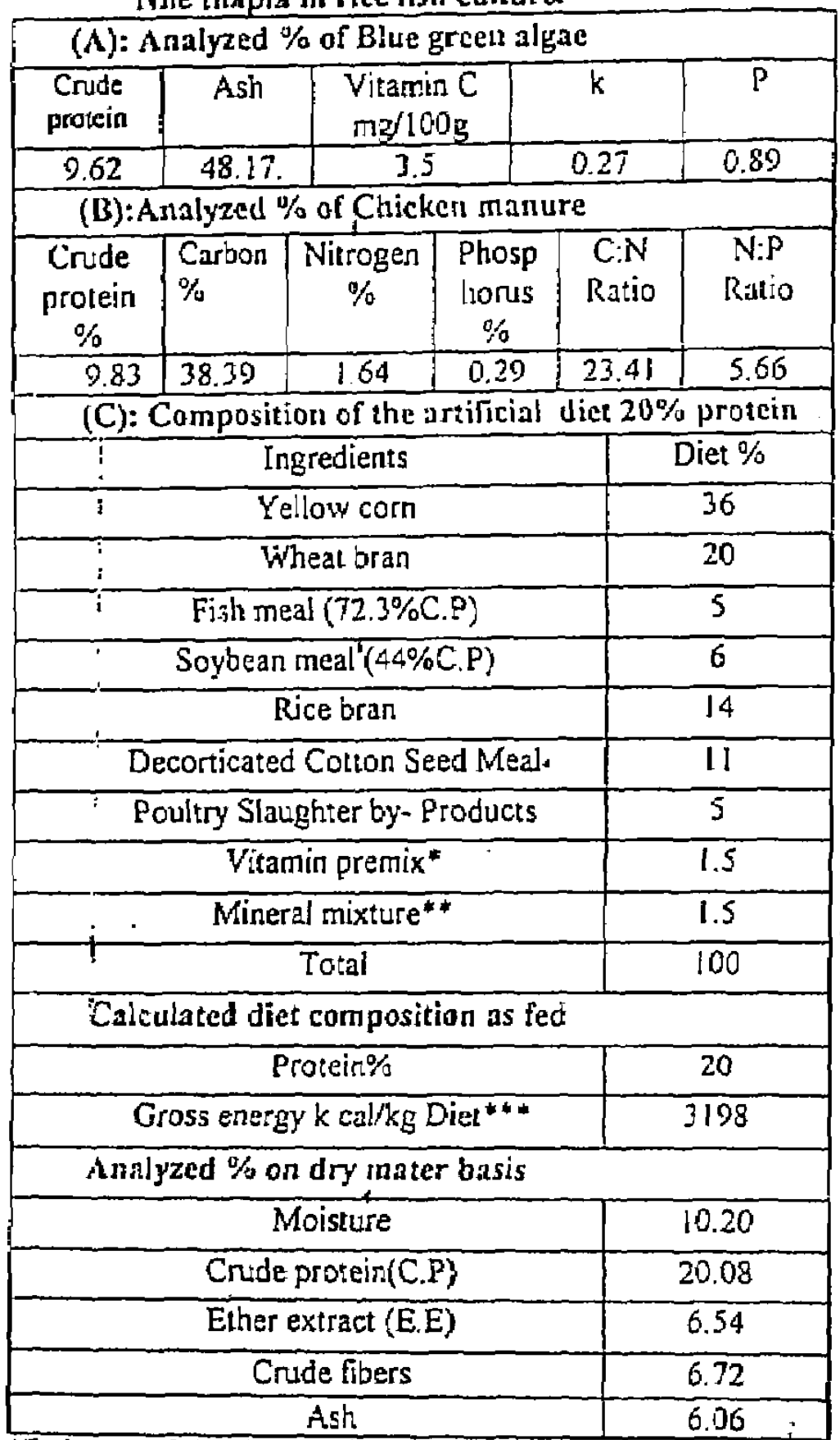

- Easch gram of vitamin premix contajns $20.000 \mathrm{fU}$ vit. A200n1U vit. D3. $410 \mathrm{vil}$. E, $20 \mathrm{mg}$ Niacin, $4.5 \mathrm{mg}$ ribollavin, $3 \mathrm{mg}$ pyridoxinc, 0.013 atg vit. B.12. $100 \mathrm{mg}$ chorine chloride and $2 \mathrm{mg}$. vit. K.

*Each gram contains $0.83 \mathrm{Ca}, 0.63 \mathrm{P}, 0.78 \mathrm{Na}, 0.018 \mathrm{Mn}, 0.011 \mathrm{Zn}$ and $0.001 \mathrm{Cu}$. The Mixlure was prepared by mixing 35 pans of dicalciutn phosphatc. 3 parts of mincral premix and 2 parts of common salt. *** According lo Jobling, (1583). 
Table (2): Average water quality parameters at paddies during the experimental Period ( 90 days).

\begin{tabular}{|c|c|c|c|c|c|c|}
\hline samples & $\begin{array}{l}\text { No } \\
\text { of } \\
\text { sam } \\
\text { ples. }\end{array}$ & $\begin{array}{l}\text { T } 1 \text { Blue } \\
\text { green } \\
\text { algae }\end{array}$ & $\begin{array}{c}T_{2} \\
\text { Diet } \\
(20 \% \\
\text { C.P) }\end{array}$ & $\begin{array}{c}\mathrm{T}_{3} \\
\text { Fertili } \\
\text { zation }\end{array}$ & $\begin{array}{l}\mathrm{T}_{4} \\
\text { (control) }\end{array}$ & Averages \\
\hline Temp C & 15 & $\begin{array}{l}26.55 \\
\dot{G} \pm 1.57\end{array}$ & $\begin{array}{l}26.16 \pm \\
0.88\end{array}$ & $\begin{array}{l}28 \pm \\
0.33\end{array}$ & $\begin{array}{l}25 \pm \\
1.20\end{array}$ & $\begin{array}{l}26.42 \pm \\
0.99\end{array}$ \\
\hline $\begin{array}{l}\text { Dissolved } \\
\text { oxygen } \\
\text { (mg/l) }\end{array}$ & 15 & $\begin{array}{l}6.42 \\
\pm 0.44\end{array}$ & $\begin{array}{l}6.15 \pm \\
0.76\end{array}$ & $\begin{array}{l}6.12 \pm \\
0.44\end{array}$ & $\begin{array}{l}7.00 \pm \\
.57\end{array}$ & $\begin{array}{l}6.42 \pm \\
0.55\end{array}$ \\
\hline $\begin{array}{l}\text { Total } \\
\text { phosphor } \\
\text { (mg/(L) }\end{array}$ & 15 & $\begin{array}{l}0.73 \\
\pm 0.24\end{array}$ & $\begin{array}{l}0.51 \pm \\
0.16\end{array}$ & $\begin{array}{l}0.81 \pm \\
0.06\end{array}$ & $\begin{array}{l}0.43 \pm \\
0.01\end{array}$ & $\begin{array}{l}0.62 \pm \\
0.11\end{array}$ \\
\hline $\begin{array}{l}\text { Sviiable } \\
\text { phosphorus } \\
(\mathrm{mg} / \mathrm{L})\end{array}$ & 15 & $\begin{array}{l}0.21 \pm \\
0.08\end{array}$ & $\begin{array}{l}0.10 \pm \\
0.01\end{array}$ & $\begin{array}{l}0.24 \pm \\
0.01\end{array}$ & $\begin{array}{l}0.31 \pm \\
0.05\end{array}$ & $\begin{array}{l}0.21 \pm \\
0.03\end{array}$ \\
\hline No $(\mathrm{mg} / \mathrm{L})$ & 15 & $\begin{array}{l}0.39 \\
\pm 0.06\end{array}$ & $\begin{array}{l}0.34 \pm \\
0.02\end{array}$ & $\begin{array}{l}0.58 \pm \\
0.04\end{array}$ & $\begin{array}{l}0.28 \pm \\
0.03\end{array}$ & $\begin{array}{l}0.39 \pm \\
0.03\end{array}$ \\
\hline $\begin{array}{l}\mathrm{NH}_{4} \\
(\mathrm{mg} / \mathrm{L})\end{array}$ & 15 & $\begin{array}{l}0.58 \\
\pm 0.12\end{array}$ & $\begin{array}{l}0.67 \pm \\
0.02\end{array}$ & $\begin{array}{l}0.78 \pm \\
0.4\end{array}$ & $\begin{array}{l}0.53 \pm \\
0.1\end{array}$ & $\begin{array}{l}0.64 \pm \\
0.16 \\
\end{array}$ \\
\hline $\mathrm{PH}$ & 15 & $\begin{array}{l}9.2 \\
\pm 0.13\end{array}$ & $\begin{array}{l}9.0 \pm \\
.02\end{array}$ & $\begin{array}{l}8.1 \pm \\
0.23\end{array}$ & $\begin{array}{l}9.41 \pm \\
0.12 \\
\end{array}$ & $\begin{array}{l}8.9 \pm \\
0.12\end{array}$ \\
\hline Alkalinity & 15 & $\begin{array}{l}323 \\
\pm 50.8\end{array}$ & $\begin{array}{l}308 \pm \\
50.2\end{array}$ & $\begin{array}{l}335 \pm \\
40.8 \\
\end{array}$ & $\begin{array}{l}301 \pm \\
50.7 \\
\end{array}$ & $\begin{array}{l}316.75 \pm \\
48.12 \\
\end{array}$ \\
\hline
\end{tabular}


Table (3): L.east square means and standard errors for plankton abundance in all experimental groups.

\begin{tabular}{|c|c|c|c|c|}
\hline 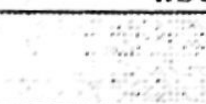 & \multicolumn{4}{|c|}{ Phytoplankton (Organisms) L } \\
\hline Treatments & $\begin{array}{l}\text { Chloro } \\
\text { phyta }\end{array}$ & $\begin{array}{l}\text { Cyan } \\
\text { ophyta }\end{array}$ & $\begin{array}{c}\text { Bacill } \\
\text { arophyta }\end{array}$ & $\begin{array}{c}\text { Total. phyto } \\
\text { plankton }\end{array}$ \\
\hline & $\hbar A \hbar$ & an: & 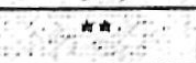 & int \\
\hline$T r_{1}$ & $2493 \pm 60.3$ & $1380 \pm 30.5$ & $1221 \pm 31.0$ & $5094 \pm 105.3$ \\
\hline $\mathrm{Tr}_{2}$ & $1850 \pm 603$ & $1013 \pm 30.5$ & $810 \pm 31.0$ & $3673 \pm 105.3$ \\
\hline $\mathrm{Tr}_{3}$ & $2481 \pm 60.3$ & $1335 \pm 30.5$ & $1110 \pm 31.0$ & $4926 \pm 105.3$ \\
\hline $\mathrm{Tr}_{4}$ & $2431 \pm 60.3$ & $1211 \pm 30.5$ & $890 \pm 31.0$ & $4532 \pm 105.3$ \\
\hline \multicolumn{5}{|c|}{ Zooplankton (Organisms)L } \\
\hline Treatment & Rotifer & Copepod & Cladocera & $\begin{array}{c}\text { Total } \\
\text { zooplankton }\end{array}$ \\
\hline & **: & 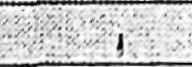 & $* *$ & $* * *$ \\
\hline$\Gamma r_{1}$ & $1452 \pm$ & $898 \pm 35.5$ & $672 \pm 29.1$ & $3022 \pm 107.3$ \\
\hline$T_{r_{2}}$ & $1350 \pm 29.3$ & $818 \pm 33.5$ & $515 \pm 29.1$ & $2683 \pm 107.3$ \\
\hline $\mathrm{Tr}_{3}$ & $1412 \pm 29.5$ & $891 \pm 33.3$ & $650 \pm 29.1$ & $2953 \pm 107.3$ \\
\hline $\mathrm{Tr}_{4}$ & $1352 \pm 29.5$ & $898 \pm 33.3$ & $672 \pm 29.1$ & $2839 \pm 107.3$ \\
\hline
\end{tabular}

+ Mean of 12 salumples ( 2 replicates and 6 samples for each replicate)

$* * P<1.01 \quad * * P<0.001$

Table (4): Growth performance of Nile tilapia (Oreochromis niloticus) as affected by varying feeding inputs.

\begin{tabular}{|l|c|c|c|c|}
\hline \multicolumn{1}{|c|}{ Treatments } & $\mathrm{T}_{1}$ & $\mathrm{~T}_{2}$ & $\mathrm{~T}_{3}$ & $\mathrm{~T}_{4}$ \\
\hline $\begin{array}{l}\text { Initial Body Wcight } \\
(\mathrm{g})\end{array}$ & 30.12 & 30.12 & 30.12 & 30.12 \\
\hline $\begin{array}{l}\text { Final Body weight } \\
(\mathrm{g})\end{array}$ & $108.10 \pm 1.38$ & $120.70 \pm 1.48$ & $91.71 \pm 1.50$ & $78.13 \pm 1.35$ \\
\hline Weight gain (g) & 77.98 & 90.58 & 61.59 & 48.01 \\
\hline Daily gain (g) & 0.86 & 1.00 & 0.68 & 0.53 \\
\hline Initial Body length & 6.24 & 6.24 & 6.24 & 6.24 \\
\hline $\begin{array}{l}\text { Final Body length } \\
\text { cIn }\end{array}$ & $13.70 \pm 0.71$ & $14.95 \pm 0.71$ & $12.97 \pm 0.71$ & $10.97 \pm 0.70$ \\
\hline $\begin{array}{l}\text { Condition factor } \\
\text { (K) }\end{array}$ & $4.20 \pm 0.23$ & $3.61 \pm 0.12$ & $4.2 \pm 0.20$ & $5.91 \pm 0.36$ \\
\hline S.G.R & 1.4 & 1.5 & 1.2 & 1.05 \\
\hline
\end{tabular}


Table (5): Economic efficiency (\%) for Nile tilapia (Oreochromis niloticus) as affected by varying feeding inputs.

\begin{tabular}{|c|c|c|c|c|}
\hline Item & $\mathrm{T}_{\mathrm{i}}$ & $\mathrm{T}_{2}$ & $\mathrm{~T}_{3}$ & $\mathrm{~T}_{4}$ \\
\hline \multicolumn{5}{|l|}{ Stocking data } \\
\hline $\begin{array}{l}\text { Stocking rate } \\
\text { (No/fed) }\end{array}$ & 1000 & 1000 & 1000 & 1000 \\
\hline $\begin{array}{l}\text { Average size at } \\
\text { stoking }(\mathrm{g})\end{array}$ & 30 & 30 & 30 & 30 \\
\hline $\begin{array}{l}\text { Average size at } \\
\text { harvesting }\end{array}$ & 108.10 & 120.70 & 91.71 & 78.13 \\
\hline Survival rate $\%$ & 95.0 & 96.0 & 93.0 & 92.0 \\
\hline \multicolumn{5}{|l|}{ Production Kg. /fed. } \\
\hline Rice & 3300 & 3200 & 3180 & 3050 \\
\hline Fish & 102.69 & 115.87 & 85.29 & 75.66 \\
\hline \multicolumn{5}{|l|}{ A- Operating costs } \\
\hline Fish fingerlings & 100 & 100 & 100 & 100 \\
\hline Rice seeds & 75 & 75 & 75 & 75 \\
\hline Food & - & 400 & - & - \\
\hline fertilization & - & - & 75 & - \\
\hline Labor & 500 & 500 & 500 & 500 \\
\hline $\begin{array}{l}\text { Blue green } \\
\text { algae }\end{array}$ & 18 & 1 & - & . \\
\hline Land renting & 600 & 600 & 600 & 600 \\
\hline Total costs/feddan & 1293 & 1675 & 1350 & 1275 \\
\hline \multicolumn{5}{|l|}{ B- Returns } \\
\hline Rice & 2640 & 2560 & 2544 & 2440 \\
\hline Fish & 513.45 & 578.35 & 426.45 & 359.35 \\
\hline Total Returns / Fed & 3153.45 & 3138.35 & 2970.45 & 2799.35 \\
\hline Net returns & 1860.45 & 1463.35 & 1620.45 & 1524.3 \\
\hline $\begin{array}{l}\text { C- } \% \text { Net returns to } \\
\text { operating cost }\end{array}$ & 143.8 & 87.36 & 120.03 & 119.55 \\
\hline
\end{tabular}

The cconomical cvaluation of results was carricd out according to market prices in 2002 in L.E. 